\title{
The Efficiency of Credit Portfolio Management in Pakistan's Banking Sector
}

\author{
Syed M. Waqar Azeem Naqvi,, Tahseen M. Khan, ${ }^{* *}$ Sayyid \\ Salman Rizavi ${ }^{* * *}$
}

\begin{abstract}
This study highlights the differences in performance of commercial banks operating in Pakistan in the context of credit portfolio management. Specifically, we look at their credit allocation policies and outcomes in the shape of nomperforming loans (NPLS). We categorize a sample of 34 banks into four major groups: public, private, Islamic and foreign banks. The study tests several hypotheses related to the overall efficiency of banks' credit portfolio management over time as well as the drivers of NPLs and priority sectors for lending across these four categories. The findings broadly suggest that public banks tend to suffer most from NPLs, whereas Islamic and foreign banks manage their portfolios more efficiently. NPLs are highest in the priority lending sectors across all types of banks, which underscores the inefficiency of managerial decision-making when managing credit portfolios. Over time, at an aggregate level, all four types of banks have become less efficient, as reflected by the increase in NPLs as a percentage of gross credit and assets.
\end{abstract}

Keywords: credit portfolio, nonperforming loans, priority sector lending.

JEL classification: G10, G20, G21.

\section{Introduction}

As financial intermediaries, commercial banks lend to the industry and services sectors; this not only boosts economic activity, but also provides returns to stakeholders. The main hurdle in achieving the desired results is the risk of nonpayment and subsequent default by borrowers. These nonperforming loans (NPLs) create a significant additional cost for banks (Maggi \& Guida, 2011) and lower their return on capital. This, in turn, can jeopardize banks severely, given the highly leveraged capital

\footnotetext{
* Assistant professor, University of Sargodha, Lahore Campus.

** Assistant professor, School of Business and Economics, University of Management and Technology.

**** Associate professor, Hailey College of Commerce, University of the Punjab.
} 
structure of the banking industry (Doyran, 2012). NPLs can also create a liquidity crisis that may be manageable initially, but still carries the risk of shattering depositors' confidence and even leading to a bank run or complete insolvency (Arif \& Anees, 2012). Nonetheless, NPLs can be managed. The regularity authority in Pakistan instructs banks to create loan loss reserves, particularly against consumer loans, which have a higher default rate. Banks also learn from experience and thus higher NPL levels are usually associated with higher levels of loan loss reserves (Hasan \& Wall, 2004).

Some banks develop models to calculate loan loss provisions on the basis of NPLs (Isa, Choong \& Fie, 2013). Despite such protection mechanisms and buffers, it is a bank's managerial structure and efficiency that also plays a pivotal role in dealing with NPLs. There is strong evidence that changes in management structure, primarily through privatization, can improve a bank's performance by significantly reducing its NPLs (Ijaz, Haq, Naseem \& Iqbal, 2012).

It is equally important for banks to be aware of the effects of macroeconomic shocks on the sectors and industries to which they have given loans. The effect of the same shock can vary across sectors (Belgrave, Guy \& Jackman, 2012), which means adopting a dynamic and robust approach to managing NPLs. A more conservative or aggressive strategy may be warranted, depending on the overall economic situation and need for credit (Balla \& McKenna, 2009). Apart from general macroeconomic shocks, banks have to be cautious when managing the effect of shocks in the context of key NPL drivers such as the interest rate. An interest rate hike will always put the borrower in a difficult situation since most of these loans are floating rate loans and any increase in the interest rate could give rise to an NPL (Bofondi \& Ropele, 2011).

Another important, if relatively ignored, dimension of analyzing NPLs is the bank's lending behavior and choice of priority sectors for lending. Both these depend heavily on the managerial and governance structure of a bank or cluster of banks operating in a particular economy (Hou \& Dickinson, 2007). However, the outcome of a particular choice of priority sectors cannot be generalized: the literature yields mixed results. Some studies suggest that priority sector lending does not benefit the bank's overall profitability (Sharma, 2005). At the same time, major defaulters are often big borrowers from nonpriority sectors (Premnath, Balachandran \& James, 2013). 
The discussion above establishes the importance of analyzing the performance of Pakistan's banking sector across managerial structures and types in the context of credit portfolio management. We focus on the credit portfolios managed by different types of banks and the infection ratio associated with the level of NPLs. The data for this study was drawn from the annual reports of a sample of 34 banks divided into four categories: public, private, Islamic and foreign banks. We employ both panel as well as pooled data where appropriate.

The study yields mixed results, suggesting that Islamic banks manage their credit portfolios more efficiently: NPLs account for a smaller percentage of their gross credit portfolios than in the other cases. Foreign banks appear to be more efficient if we measure NPLs as a percentage of average total assets over the sample period 2008-12. There is sound evidence that public banks suffer most from NPLs when measured as a percentage of average gross credit portfolios and average total assets. Regardless of the rising trend in the level of NPLs, which indicates deteriorating efficiency, commercial banks' assets and credit portfolios have also increased over time.

The study also looks at the outcome of management decisions to lend to selected priority sectors by analyzing the breakup of NPLs. The results suggest that the category "other sectors" accounts for the largest volume of credit in nominal terms, although the textiles sector is clearly a priority sector in terms of its average share of gross credit portfolios over the sample period. These choices are not necessarily optimal for banks: both sectors are associated with a high infection ratio.

Section 2 provides an overview of the banking sector and describes the dataset. Section 3 outlines our hypotheses and methodology. Section 4 discusses the results and policy implications. Section 5 concludes the study.

\section{A Profile of Pakistan's Banking Sector}

We have extracted the relevant data from the annual financial statements of 34 commercial banks operating in Pakistan over the five-year period 2008-12. These include public, private, foreign and Islamic banks. The data comprises observations for different variables, including gross credit portfolios, assets, deposits, lending by sector, classification of sectors, credit provisions by sector, profits and other performance and structural variables. In order to manage the data better, we have merged the loans in about 55 business sectors into 11 sectors as follows: 
- Agriculture: agriculture, forestry and hunting, tobacco and cigarette manufacture, fishing, farming, cattle and dairy, fertilizers, wool.

- Engineering: basic metals, engineering and surgical goods, machinery and equipment, transport equipment and automobiles, cables, electronics and electrical appliances, mining and quarrying.

- Foods: ghee and edible oils, grains and related foods, beverages, foods and allied products, rice processing and trading, sugar.

- Services: education, containers and ports, hotels, rest-houses and clubs, health and social welfare, housing and trusts, media, travel agencies, transport, storage, communications and services, IT and telecommunication, financial institutions and investment companies, services (other than finance, hotels and travel), infrastructure.

- Construction: construction (glass and ceramics), RE, renting and bus activities, cement, clay and ceramics.

- Nonengineering: footwear and leather garments, shoes, furniture and sports goods, printing, publishing and allied products, paper and paper-board, carpets, chemicals and pharmaceuticals, rubber and plastic, plastic products, synthetic and rayon.

- Power: petroleum products, fuel and energy, power, gas, water and sanitary products.

- Textiles: spinning, weaving, finishing, made-ups, readymade garments.

- Trade: import and export, wholesale and retail trade.

- Individuals.

- Other sectors.

Figure 1 provides a snapshot of the size of gross credit portfolios and assets in the banking sector. Despite a tremendous increase in the asset base from almost PRs 5.3 trillion to PRs 9.5 trillion, gross credit portfolios increased by merely PRs 0.9 trillion to a total of PRs 4.1 trillion. 
Figure 1: Gross credit portfolio and asset base of the banking sector

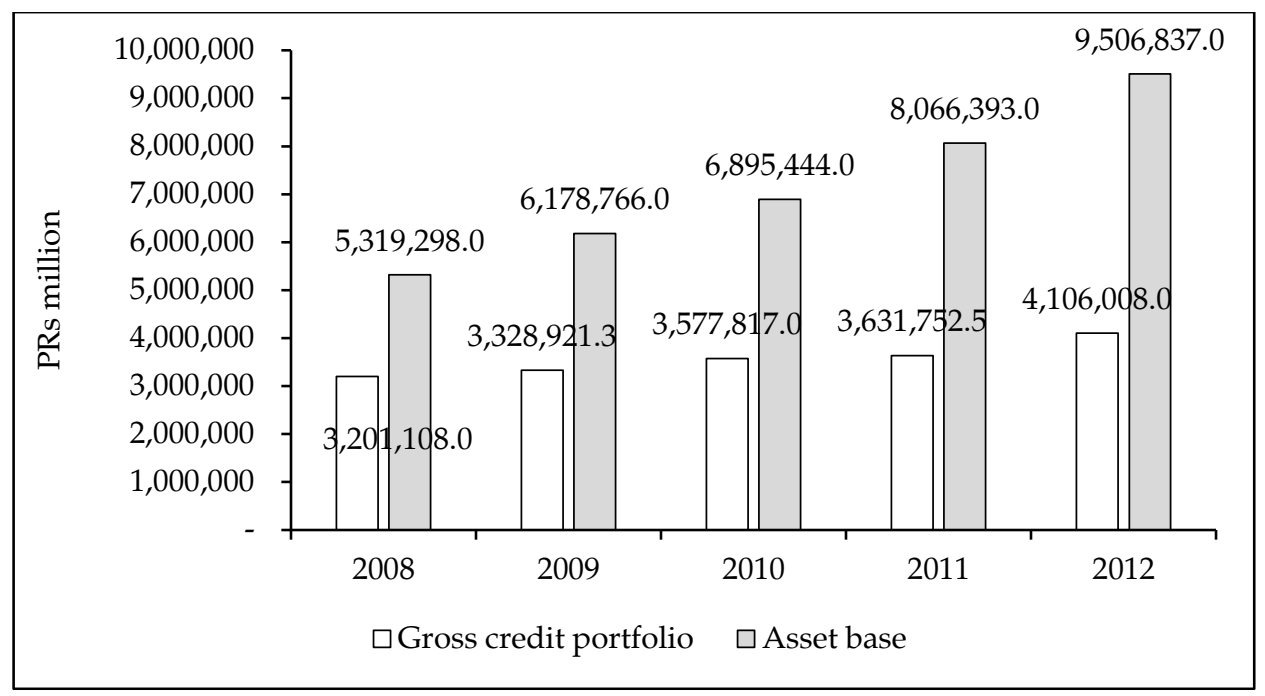

Figure 2 compares growth rates in gross credit portfolios and assets across the four types of banks. Foreign banks experienced relatively little growth in assets, except in 2012, when the asset base grew by 35 percent (led primarily by the growth in assets for Barclays). Islamic banks grew consistently by more than 30 percent while sustaining their primary function (lending), with credit portfolios rising by 27 percent annually. In the last year of the sample period, their lending increased by almost 43 percent. Public banks increased their lending by a massive 45.9 percent despite the small increase in assets. Private banks registered a reasonable asset growth rate, but extended little credit; the percentage change in their credit portfolios remained volatile. This is likely due to the government's deficit financing. The government borrowed heavily from private banks during this period, while the latter earned reasonable returns simply by investing in government papers during 2009-12. 
Figure 2: Gross credit portfolio and asset base, by type of bank
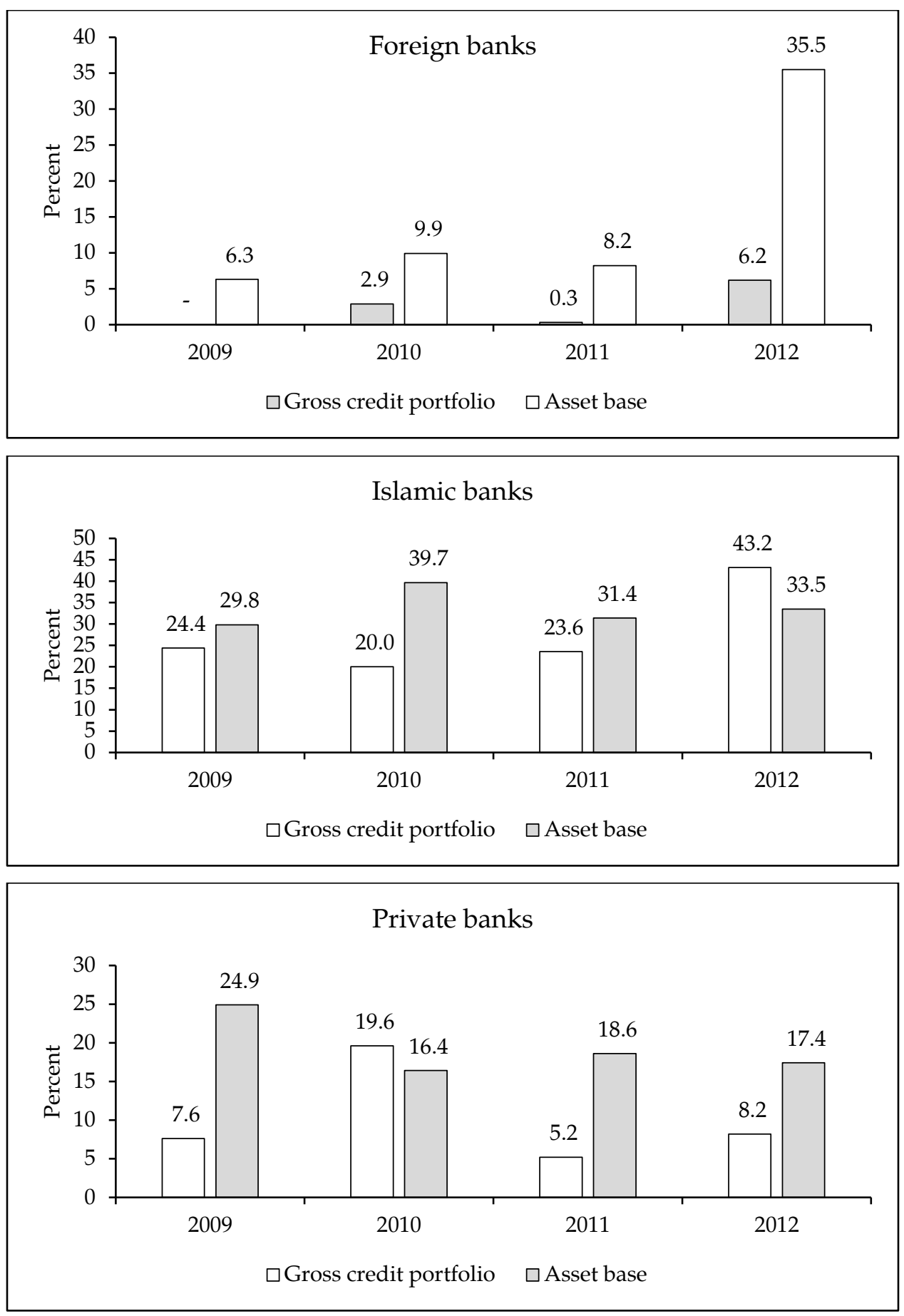


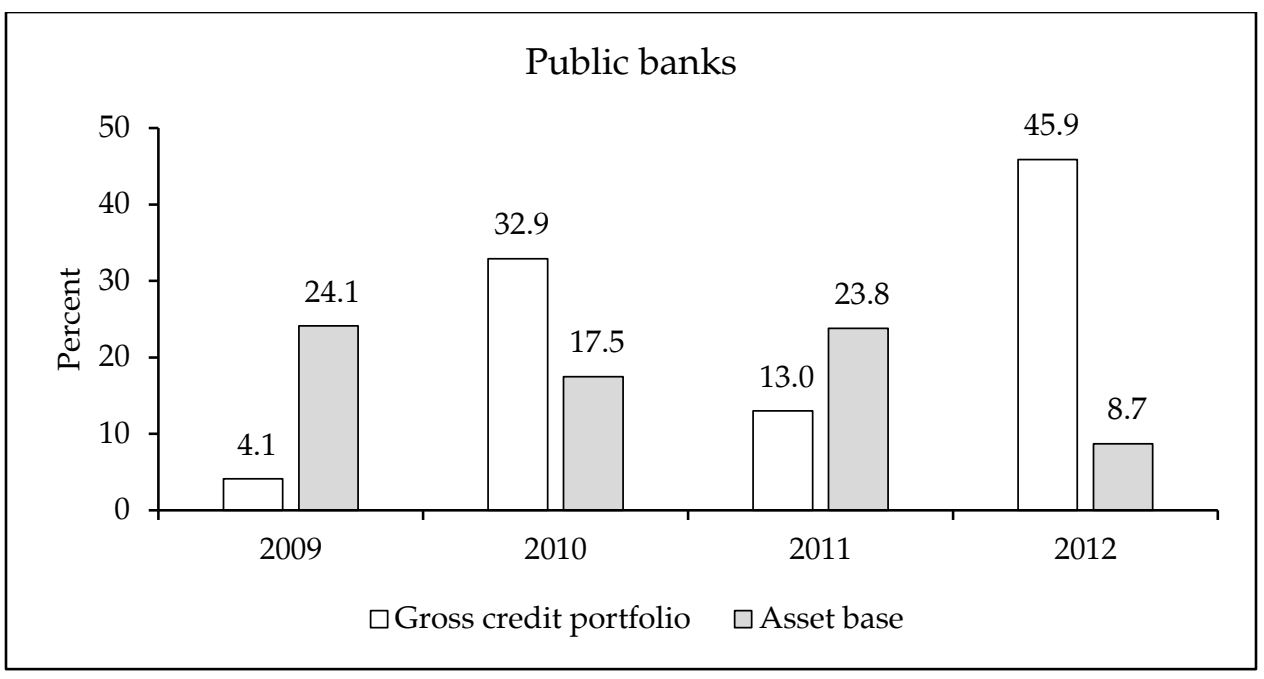

Figure 3 and Table 1 provide a more recent picture of credit portfolios and market shares across different types of banks. In 2012, private banks were the largest providers of credit, extending more than PRs 2.86 trillion or approximately 70 percent of the total credit provided by the banking sector that year.

Figure 3: Gross credit portfolios of banks, 2012

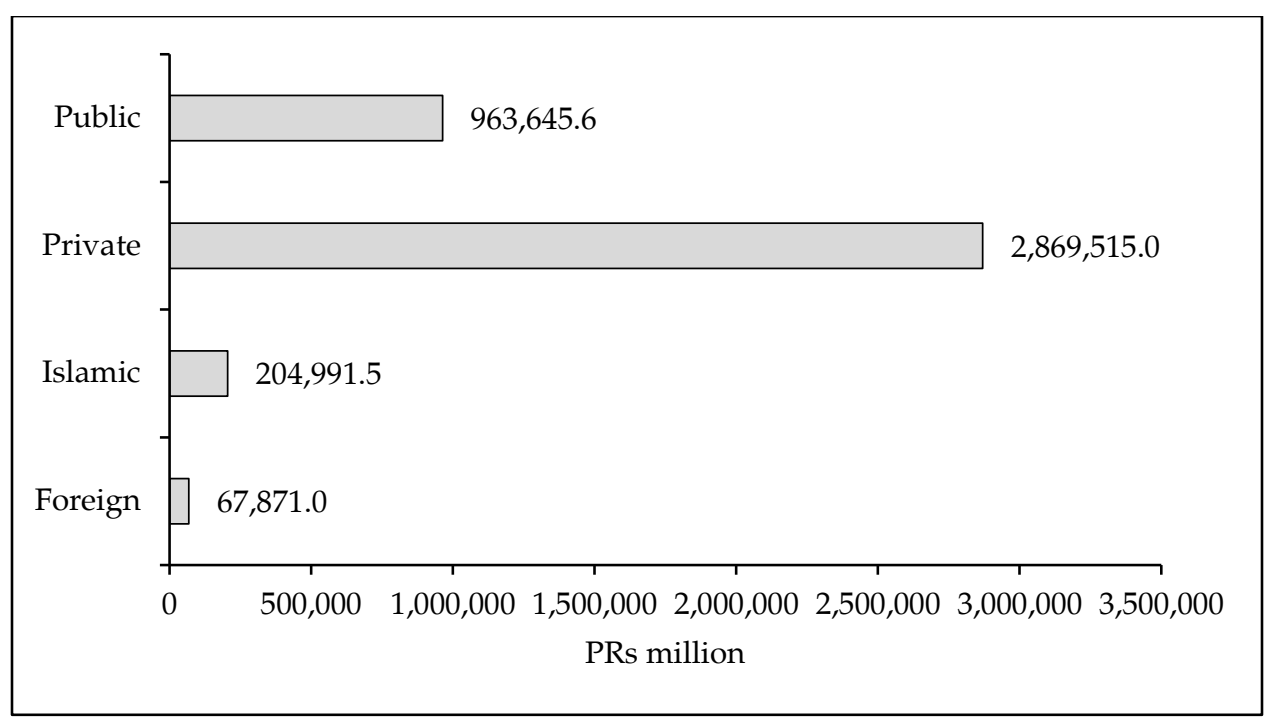


Table 1: Gross credit portfolios of banks, 2012

\begin{tabular}{lcccc}
\hline \multicolumn{1}{c}{ Type } & $\begin{array}{c}\text { Total credit } \\
\text { PRs million }\end{array}$ & $\begin{array}{c}\text { Market share } \\
\%\end{array}$ & $\begin{array}{c}\text { Banks } \\
\text { Number }\end{array}$ & $\begin{array}{c}\text { Average credit } \\
\text { PRs million }\end{array}$ \\
\hline Foreign & 67,871 & 1.7 & 7 & $9,695.9$ \\
Islamic & 204,998 & 5.0 & 5 & $40,999.6$ \\
Private & $2,869,515$ & 69.9 & 17 & $168,795.0$ \\
Public & 963,624 & 23.5 & 5 & $192,724.8$ \\
All & $4,106,008$ & 100.0 & 34 & $120,764.9$ \\
\hline
\end{tabular}

Source: Authors' calculations.

Assets reflect a similar pattern. As Figure 4 and Table 2 show, private banks account for PRs 6.9 trillion out of PRs 9.5 trillion in total assets (almost 73 percent). The average asset base of each bank in this category is almost PRs 400 billion.

Table 2: Asset base of banks, 2012

\begin{tabular}{lcccc}
\hline \multicolumn{1}{c}{ Type } & $\begin{array}{c}\text { Total credit } \\
\text { PRs million }\end{array}$ & $\begin{array}{c}\text { Market share } \\
\%\end{array}$ & $\begin{array}{c}\text { Banks } \\
\text { Number }\end{array}$ & $\begin{array}{c}\text { Average credit } \\
\text { PRs million }\end{array}$ \\
\hline Foreign & 246,744 & 2.6 & 7 & $35,249.14$ \\
Islamic & 533,228 & 5.6 & 5 & $106,645.60$ \\
Private & $6,933,016$ & 72.9 & 17 & $407,824.50$ \\
Public & $1,793,849$ & 18.9 & 5 & $358,769.80$ \\
All & $9,506,837$ & 100.0 & 34 & $279,612.90$ \\
\hline
\end{tabular}

Source: Authors' calculations.

Figure 4: Asset base of banks, 2012

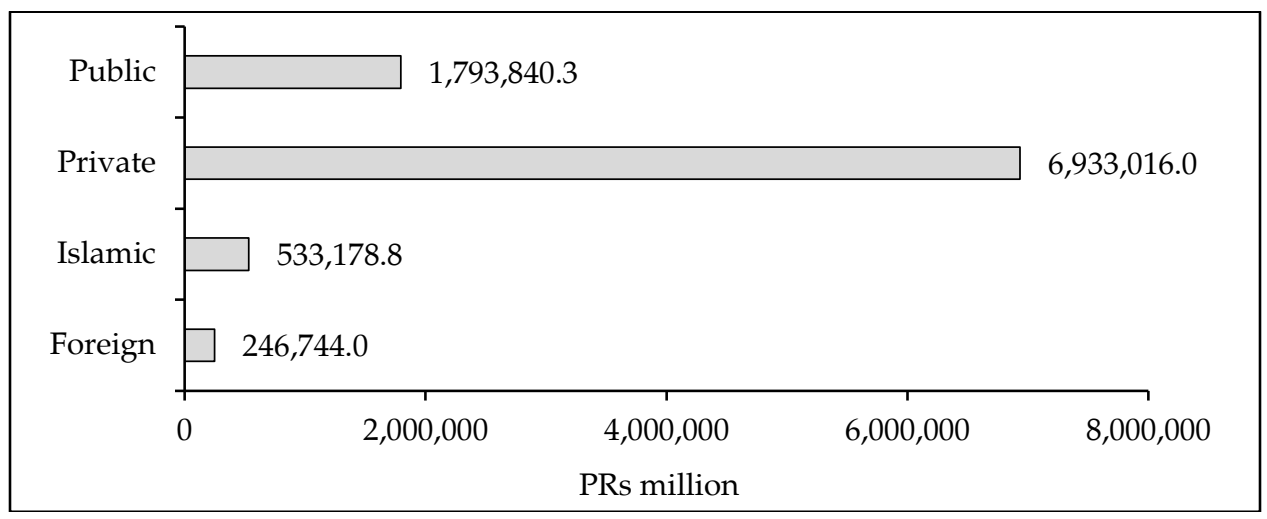

Although the data above ranks the types of commercial banks quite clearly in terms of credit portfolios and assets, one should not ignore the 
fact that Islamic banks, despite their small share of the banking industry, are growing exponentially. Almost all leading banks now have Islamic banking windows, which this study does not take into account.

\section{Hypotheses and Methodology}

We develop the following hypotheses:

- H1: X-type banks manage their credit portfolios more efficiently.

- H2: The efficiency of banks has improved over time.

- H3: NPLs are a major hurdle to managing credit portfolios.

- H4: X-type banks are jeopardized most by NPLs.

- H5: Sector Y is the main beneficiary of credit provided by all types of banks.

- H6: Sector $Y$ is the main sector responsible for generating NPLs.

- H7: Sector $\mathrm{Y}$ is a priority lending sector for $\mathrm{X}$-type banks.

The data is categorized into a balanced panel of 34 entities and five years of observations, yielding a total of 170 observations. We use the Hausman test to determine whether a random or fixed effects generalized least squares model is best. The test rejects the null hypothesis that differences in coefficients are not systematic, thus supporting the use of fixed effects regression.

Given the emphasis on the different types of banks rather than on individual banks, we apply fixed effects through a least squares dummy variable (LSDV) model instead of within-estimation or between-estimation (available in different software by default). We also examine descriptive statistics for different variables across several categories, including the type of bank and time period.

The basic LSDV model used to test $\mathrm{H} 1$ and $\mathrm{H} 4$ is:

$$
\begin{aligned}
N P L_{i, t}=\beta_{0}+ & \beta_{1} \text { Assets }+\beta_{2} \text { Credit portfolio }+\beta_{3} \text { Equity }+\beta_{4} \text { Deposits } \\
& +\beta_{5} \text { Dummy } \\
& +\varepsilon_{i, t}
\end{aligned}
$$

The dependent variable is NPL, which is measured in nominal terms as a percentage of gross credit portfolios and a percentage of assets. The independent (control) variables are as follows. Assets capture bank 
size in terms of balance sheets. Credit portfolios describe the bank's portfolio developed against lending to different business sectors. Equity is the bank's net equity. Deposits measure the money deposited by customers, payable on demand by the bank. Three dummy variables capture the performance differential of different banks: foreign, Islamic and private, where the base is public banks.

The regression model incorporates NPL and the control variables in nominal terms, as a percentage of assets and as a percentage of gross credit portfolios to check the robustness of the results. However, the results reported here are from the regression in which NPL was measured as a percentage of gross credit portfolios.

\section{Results and Policy Implications}

This section tests the hypotheses presented above.

\subsection{Efficiency by Type of Bank}

We start by looking at the infection rate of the sample in 2012. Table 3 shows that the total NPLs for all commercial banks are approximately equal to PRs 387 billion against PRs 4.1 trillion in credit portfolios and PRs 9.5 trillion in assets. Islamic banks emerge as the most efficient, with the lowest ratio of NPLs to both the asset base and credit portfolios. Public banks are the most inefficient, with the highest ratio of NPLs to assets and credit portfolios (5.5 and 10.3 percent, respectively). Private banks follow Islamic banks with the second-lowest ratio of NPLs to credit portfolios.

Table 3: NPLs against asset base and credit portfolio of banks, 2012

\begin{tabular}{lcrccc}
\hline Type & Assets & $\begin{array}{c}\text { Credit } \\
\text { portfolio }\end{array}$ & NPLs & NPLs/assets & $\begin{array}{c}\text { NPLs/credit } \\
\text { portfolio } \\
\%\end{array}$ \\
\hline Foreign & 246,744 & 67,871 & 8,327 & 3.4 & 12.3 \\
Islamic & 533,228 & 204,998 & 9,075 & 1.7 & 4.4 \\
Private & $6,933,016$ & $2,869,515$ & 271,571 & 3.9 & 9.5 \\
Public & $1,793,849$ & 963,624 & 98,996 & 5.5 & 10.3 \\
Total & $9,506,837$ & $4,106,008$ & 387,969 & 4.1 & 9.4 \\
\hline
\end{tabular}

Source: Authors' calculations.

To strengthen these findings, we determine the impact of NPLs across types of banks, using the following LSDV model: 


$$
\begin{aligned}
\frac{N P L S}{\text { Credit portfolios }} & =0.15068+0.00601 \frac{\text { Assets }}{\text { Credit portfolios }} \\
& +0.00691 \frac{\text { Equity }}{\text { Credit portfolios }}-0.03849 \frac{\text { Deposits }}{\text { Credit portfolios }} \\
& -0.04500 \text { Dummy } \text { Foreign }-0.05855 \text { Dummy } \text { Islamic }_{\text {Drivate }}+\varepsilon_{i, t}
\end{aligned}
$$

To ensure the robustness of the results, we run a regression where NPLs are measured as a percentage of gross credit portfolios and assets. The control variables include assets, equities and deposits, each as a percentage of credit portfolios. The three dummy variables that capture the performance differential of banks are foreign, Islamic and private banks, where public banks are the base. The results reported here are from the regression in which NPLs are measured as a percentage of credit portfolios.

The negative and significant dummies for foreign and Islamic banks in Table 4 confirm the initial inference that these banks are significantly better at managing their credit portfolios than public banks. Although the average ratio of NPLs to credit portfolios is highest for foreign banks, negating the idea that they are better off than public banks, this is primarily because of an abnormal increase from 5.7 to 16.5 percent in the last year of the sample period.

Although it initially seems that private banks are better at managing their credit portfolios than public banks, the insignificant dummy for private banks indicates that this performance differential is not very meaningful. This inference is the same when we use the ratio of NPLs to assets.

Table 4: LSDV model results

\begin{tabular}{lrcrcrr}
\hline \multicolumn{1}{c}{ NPLs_GLoans } & Coefficient & SE & t & P-value & \multicolumn{2}{c}{ 95\% conf. interval } \\
\hline Assets_Gloans & 0.0060090 & 0.0017054 & 3.52 & 0.001 & 0.0026406 & 0.0093775 \\
Equity_Gloans & 0.0069072 & 0.0020120 & 3.43 & 0.001 & 0.0029331 & 0.0108813 \\
Deposits_Gloans & -0.0384888 & 0.0102423 & -3.76 & 0.000 & -0.0587192 & -0.0182584 \\
Dum_foreign & -0.0449991 & 0.0218334 & -2.06 & 0.041 & -0.0881242 & -0.0018741 \\
Dum_Islamic & -0.0585486 & 0.0221068 & -2.65 & 0.009 & -0.1022137 & -0.0148835 \\
Dum_private & -0.0125203 & 0.0180781 & -0.69 & 0.490 & -0.0482280 & 0.0231874 \\
Con & 0.1506768 & 0.0205055 & 7.35 & 0.000 & 0.1101744 & 0.1911791 \\
\hline
\end{tabular}

Source: Authors' calculations. 


\subsection{Improvements in Efficiency Over Time}

To test $\mathrm{H} 2$, we analyze the efficiency of the banking sector over the period 2008-12 by comparing trends in the yearly level of average NPLs as a proportion of gross credit portfolios. There is clearly an increasing trend in NPLs (Figure 5).

Figure 5: Ratio of yearly NPLs to average credit portfolios

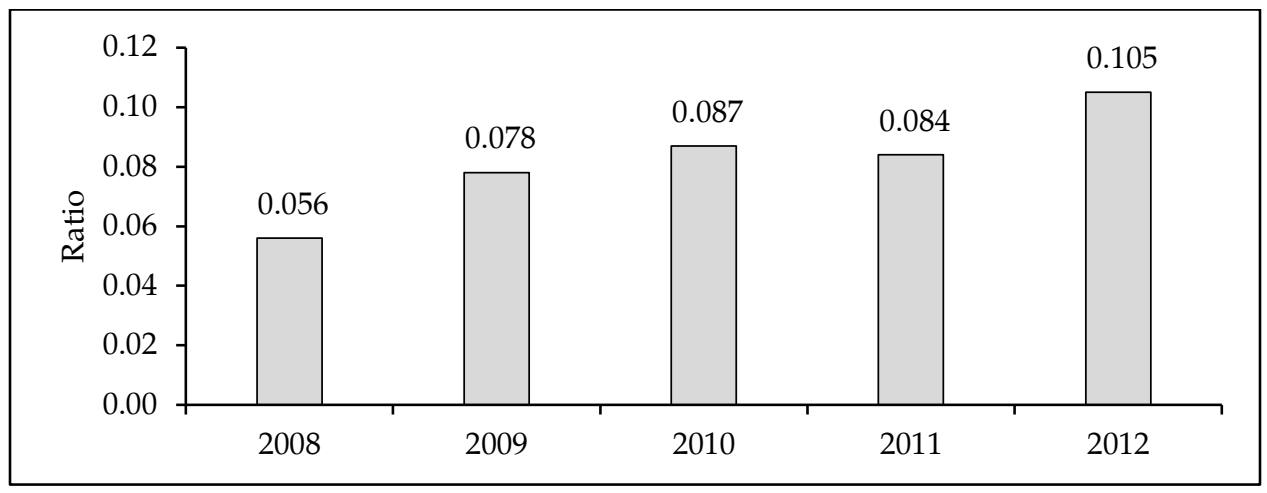

However, this trend is not apparent when we take NPLs as a proportion of the asset base (Figure 6). The contrast in the two ratios shows that, although the asset base of banks increased significantly during the sample period, they did not carry out their primary function of lending to the same degree. Instead, most of the increase in assets was absorbed by high-yield investment portfolios comprising primarily government securities. At the same time, the existing credit portfolio was affected severely by the increasing interest rate, coupled with the fact that most loans are based on a variable interest rate.

Figure 6: Ratio of yearly NPLs to assets

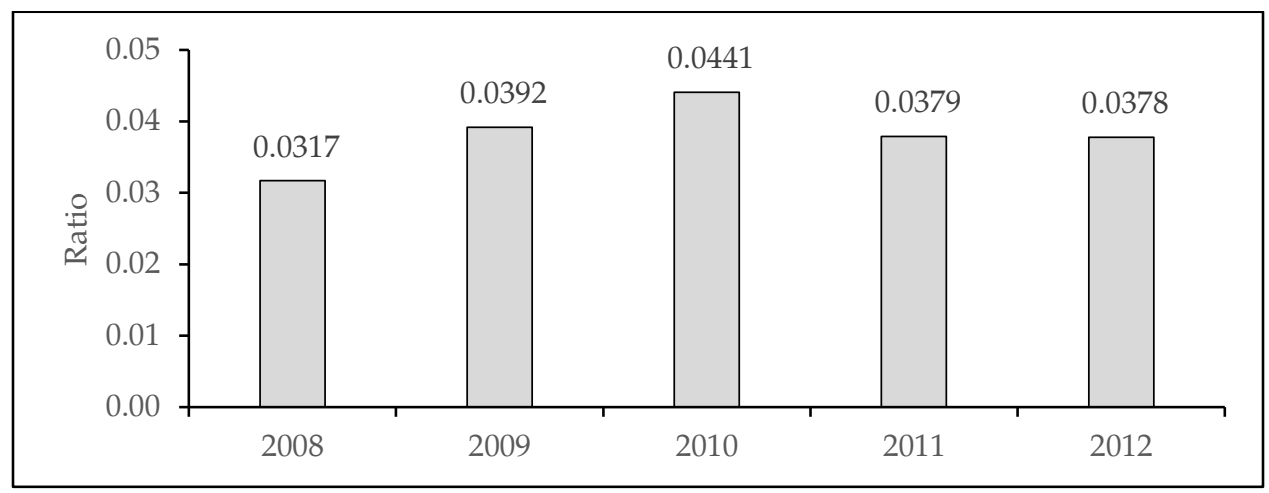


While the figures above tell us about the evolution of NPLs and the efficiency of the overall industry, they do not illustrate trends in the performance of individual categories of banks. Figure 7 shows that, although public banks carry the largest proportion of NPLs (equivalent to 10.3 percent of their credit portfolio), their performance reflects a stark improvement. This holds true for Islamic banks as well. On the other hand, private banks, which are the largest providers of credit in Pakistan, seem to have been plagued by the gradually increasing ratio of NPLs to credit over this period.

Figure 7: NPLs as a percentage of credit portfolios, by type of bank
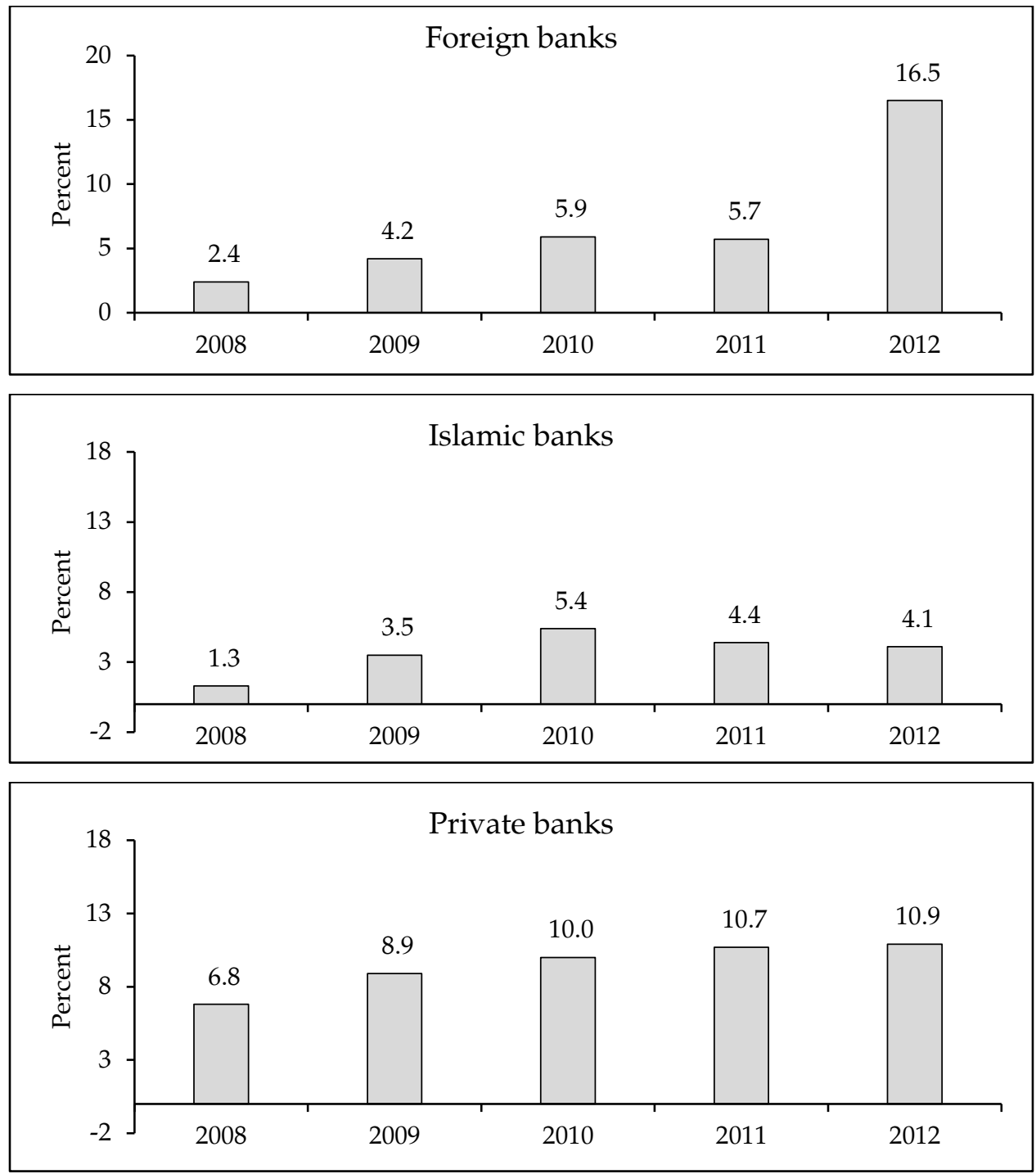


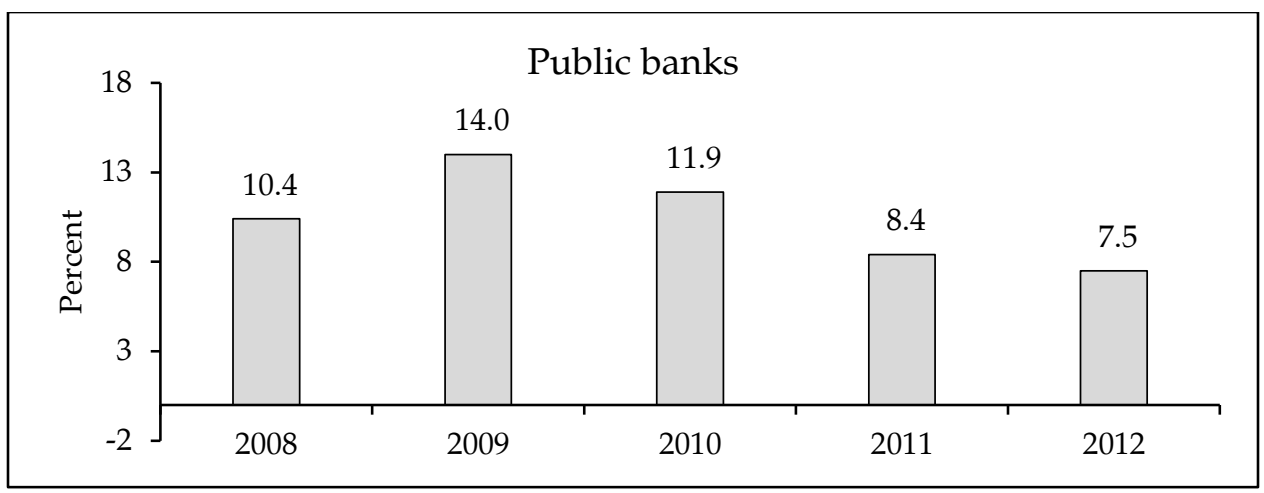

This finding is verified when we run a panel regression for each group, adding a time variable to capture the trend in performance. These trend coefficients are reported in Table 5.

Table 5: NPL trend coefficients, by type of bank

\begin{tabular}{lcccccc}
\hline & \multicolumn{3}{c}{ NPLs as \% of assets } & \multicolumn{3}{c}{ NPLs as \% of credit portfolio } \\
\cline { 2 - 7 } Type & Coefficient & SE & P-value & Coefficient & SE & P-value \\
\hline Overall & 0.0075159 & 0.0017261 & 0.000 & 0.016579 & 0.004258 & 0.0001 \\
Foreign & 0.0022732 & 0.0026333 & 0.396 & 0.042270 & 0.016558 & 0.0167 \\
Islamic & 0.0018046 & 0.0018163 & 0.332 & 0.004980 & 0.004370 & 0.2680 \\
Private & 0.0104492 & 0.0024107 & 0.000 & 0.020474 & 0.004307 & 0.0000 \\
Public & -0.0029990 & -0.0043099 & 0.496 & -0.006090 & 0.008800 & 0.4981 \\
\hline
\end{tabular}

Source: Authors' calculations.

The results above suggest that the efficiency of banks has not improved over time, both in terms of NPLs as a percentage of average gross credit portfolios and as a percentage of total assets. While public banks appear to have done better, with a negative time dummy, the variable is still insignificant in both regressions.

\subsection{NPLs as a Constraint to Managing Credit Portfolios}

We regress the credit portfolios variable on the contemporaneous and lagged values of NPL and add the contemporaneous and lagged values of deposits and equity as control variables. All variables are taken as a percentage of assets. We run regressions for the overall banking sector as well as for each group. The results reported in Table 6 suggest that neither contemporaneous nor lagged NPLs have any effect on the size of credit portfolios. The estimated coefficients for contemporaneous NPLs are negative for foreign and Islamic banks. The coefficients of lagged NPLs are 
negative for foreign and public banks, but none of these is significant, thus rejecting the hypothesis that NPLs are a major constraint to managing credit portfolios.

Table 6: Results of LSDV (lagged effect) model

\begin{tabular}{lccc}
\hline & \multicolumn{3}{c}{ Credit portfolio as \% of assets } \\
\cline { 2 - 4 } Group & Coefficient & SE & P-value \\
\hline Overall & 1.777881 & 0.600825 & 0.0037 \\
NPLs (contemporaneous) & 0.207213 & 0.580173 & 0.7216 \\
NPLs (lagged) & & & \\
Foreign & -1.244647 & 1.126518 & 0.2838 \\
NPLs (contemporaneous) & -1.506169 & 1.649270 & 0.3732 \\
NPLs (lagged) & & & \\
Islamic & -2.299673 & 3.085268 & 0.4693 \\
NPLs (contemporaneous) & 1.026400 & 2.964387 & 0.7347 \\
NPLs (lagged) & & & \\
Private & 2.338104 & 0.786017 & 0.0042 \\
NPLs (contemporaneous) & -0.432728 & 0.703672 & 0.5409 \\
NPLs (lagged) & & & \\
Public & 2.664933 & 1.446766 & 0.0953 \\
NPLs (contemporaneous) & -1.535655 & 1.476033 & 0.3227 \\
NPLs (lagged) & & & \\
\hline
\end{tabular}

Source: Authors' calculations.

\subsection{Banks Jeopardized by NPLs}

We have already analyzed the different types of banks in terms of average NPLs as a percentage of average credit portfolios and of average total assets (H1). The results of this analysis also suggest that public banks are jeopardized most by NPLs as a percentage of average gross credit portfolios and of average total assets over the sample period (Figure 5 and Table 5).

\subsection{Sector Beneficiaries of Bank Credit}

In order to identify the main beneficiary of the credit provided by commercial banks, we analyze the average annual lending by sector in nominal rupee terms. Figure 8 shows that the maximum credit (extended by all banks) is channeled to the "other" sector, equivalent to PRs 21,178.10 million in nominal terms and 19.47 percent of the average gross credit 
portfolio. The textiles sector follows, with a credit volume of PRs 20,834.7 million in nominal terms, equivalent to 19.15 percent of the average gross credit portfolio (Figure 9). These two sectors were, therefore, commercial banks' priority lending sectors during the sample period.

Figure 8: Nominal value of lending, by sector, 2008-12

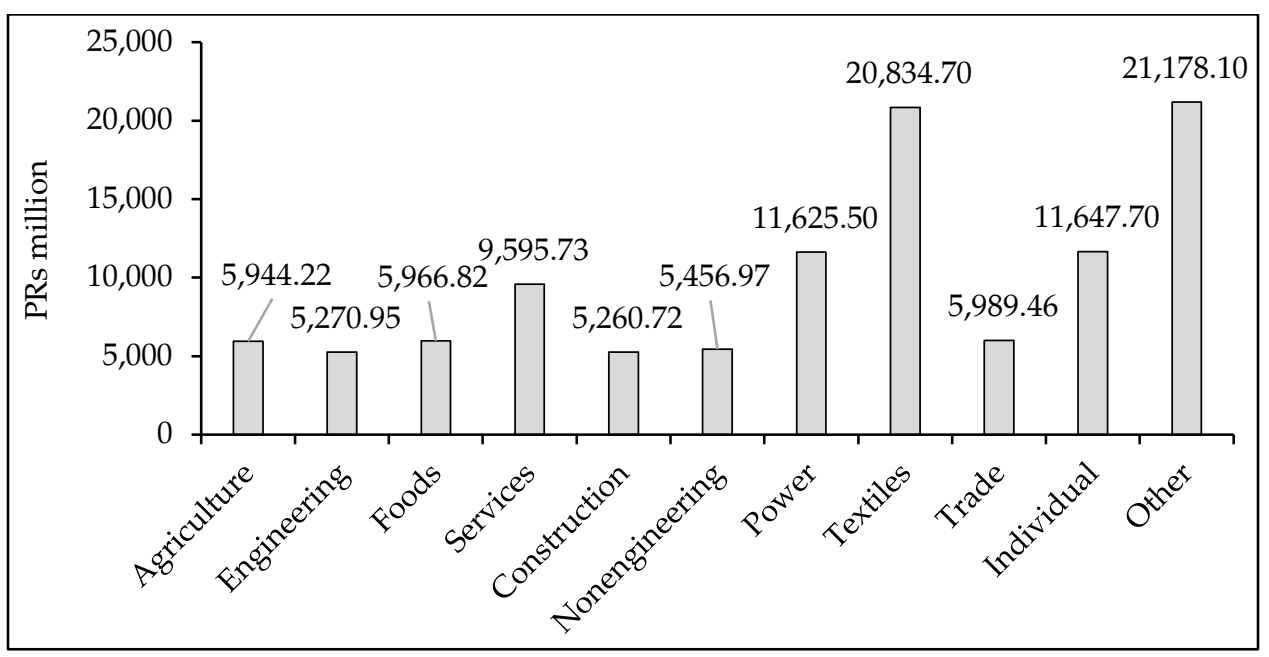

Note: The figure gives mean values.

Figure 9: Lending as a percentage of average credit portfolio, by sector, 2008-12

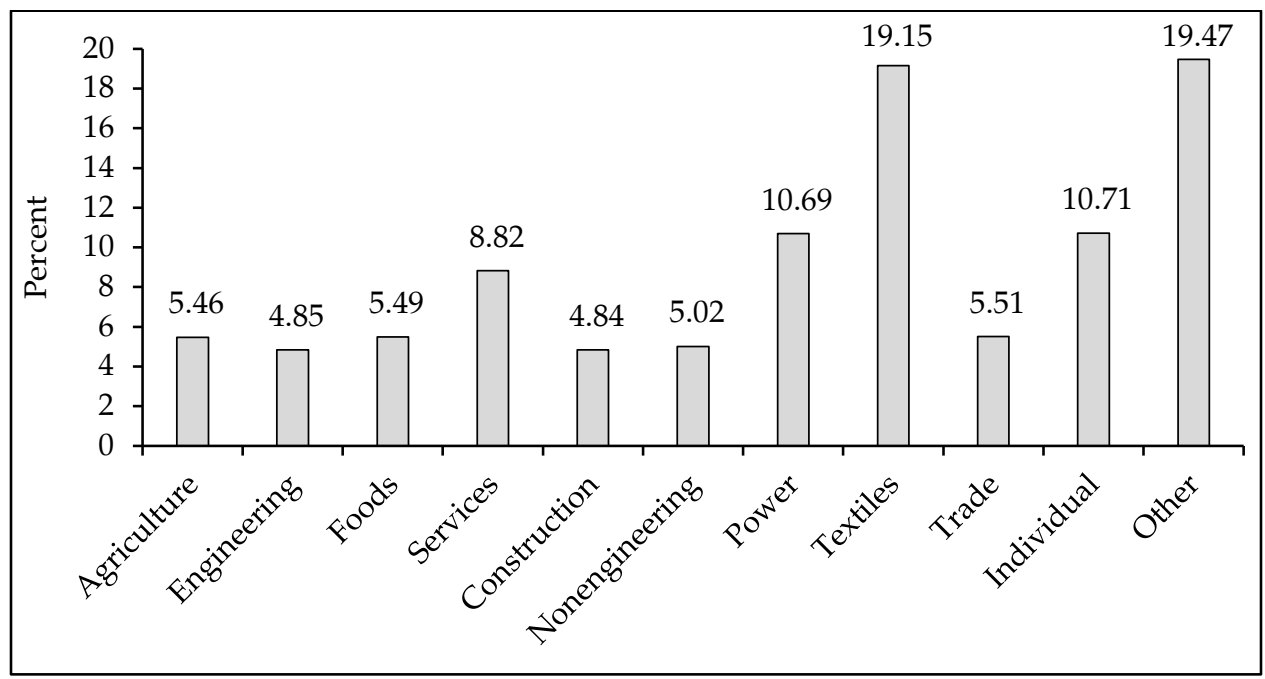

Note: The figure gives mean values. 


\subsection{Sectors Responsible for Generating NPLs}

In testing H5, it is important to gauge the outcomes of the choice of priority lending sectors to see if it benefits the sample banks. Table 7 and Figures 10 and 11 show that the textiles sector is responsible for generating the largest volume of NPLs: PRs 3,264.28 million or approximately 34.79 percent of the average total NPL level. The choice of priority sectors is, therefore, not optimal: the textiles sector is associated with the lion's share of credit.

Table 7: Average NPLs, by sector

\begin{tabular}{lcc}
\hline Sector & Nominal NPLs & NPLs as \% of total \\
\hline Agriculture & 223.06 & 2.38 \\
Engineering & 617.90 & 6.58 \\
Foods & 372.60 & 3.97 \\
Services & 367.17 & 3.91 \\
Construction & 578.60 & 6.17 \\
Nonengineering & 382.34 & 4.07 \\
Power & 355.34 & 3.79 \\
Textiles & $3,264.28$ & 34.79 \\
Trade & 721.74 & 7.69 \\
Individuals & 884.58 & 9.43 \\
Other & $1,615.99$ & 17.22 \\
\hline
\end{tabular}

Source: Authors' calculations.

Figure 10: Average NPLs, by sector, 2008-12

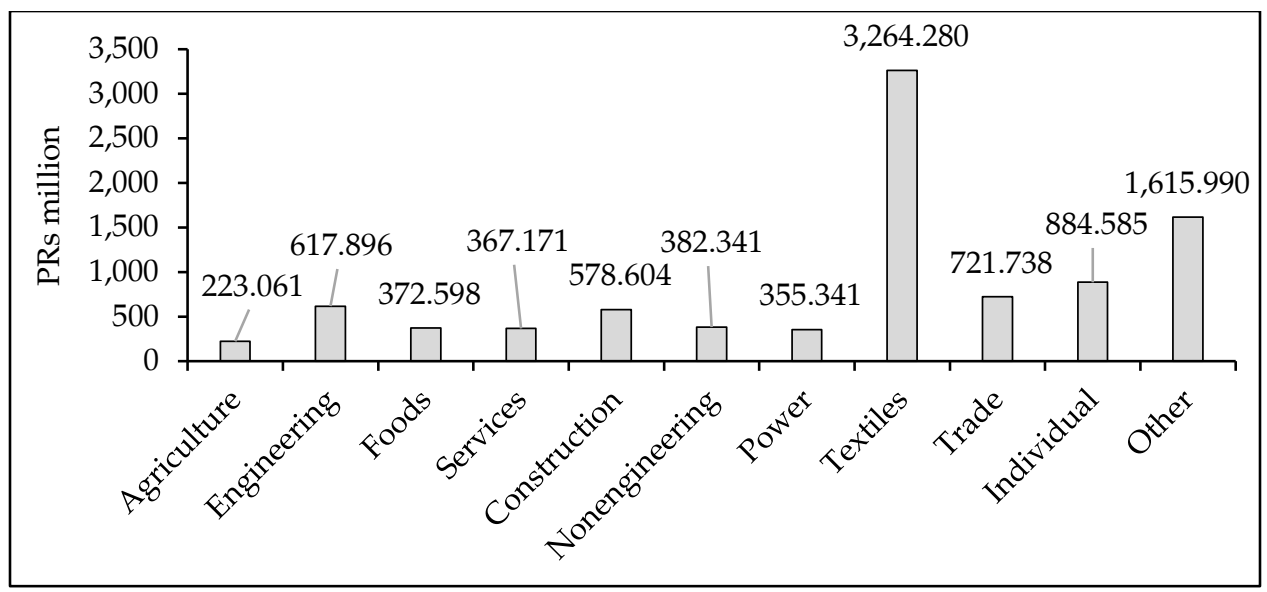

Note: The figure gives mean values. 
Figure 11: Sectoral NPLs as a percentage of total NPLs, 2008-12

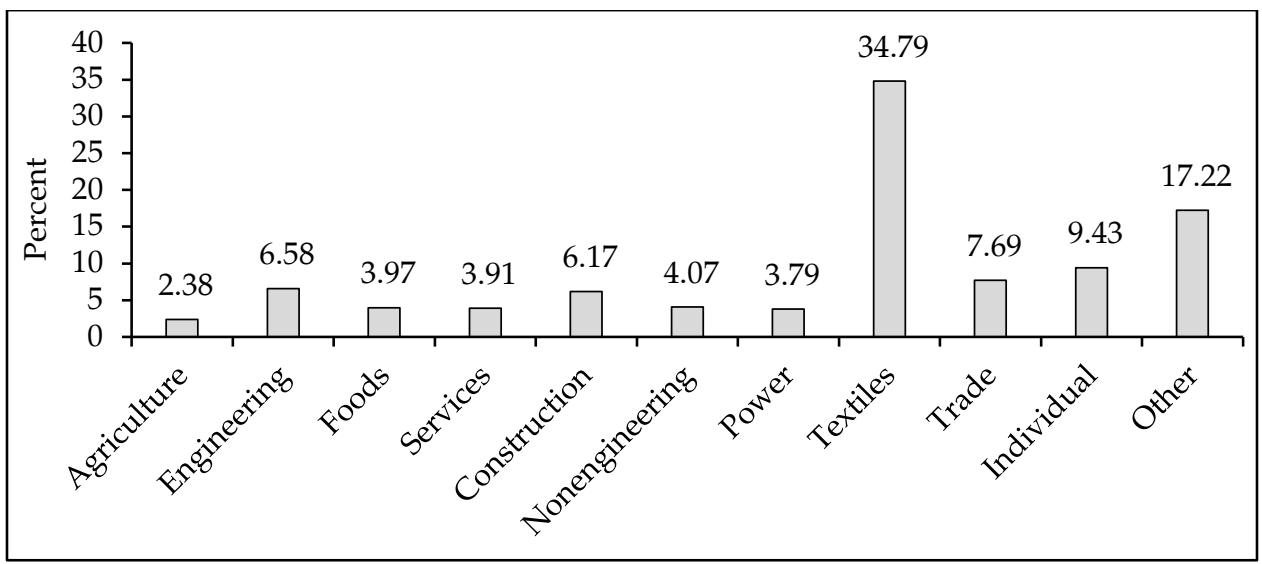

Note: The figure gives mean values.

\subsection{Priority Sectors in Bank Lending}

To understand individual banks' lending preferences, we conduct a sectoral analysis of loans across the four types of banks, looking at priority sector lending as a percentage of the total loans to all sectors. The foods sector emerges as a priority lending sector for public banks, accounting for 21 percent of the total credit they issued in the sample period. The textiles sector is a priority lending sector for private banks ( 23 percent of the total credit issued). Foreign banks appear to favor the engineering sector (23 percent of their total credit portfolio), while the textiles sector is the priority lending sector for Islamic banks (21 percent of total credit allocations). These results are presented in Figure 12.

Figure 12: Lending as a percentage of credit portfolios, by sector, 2008-12

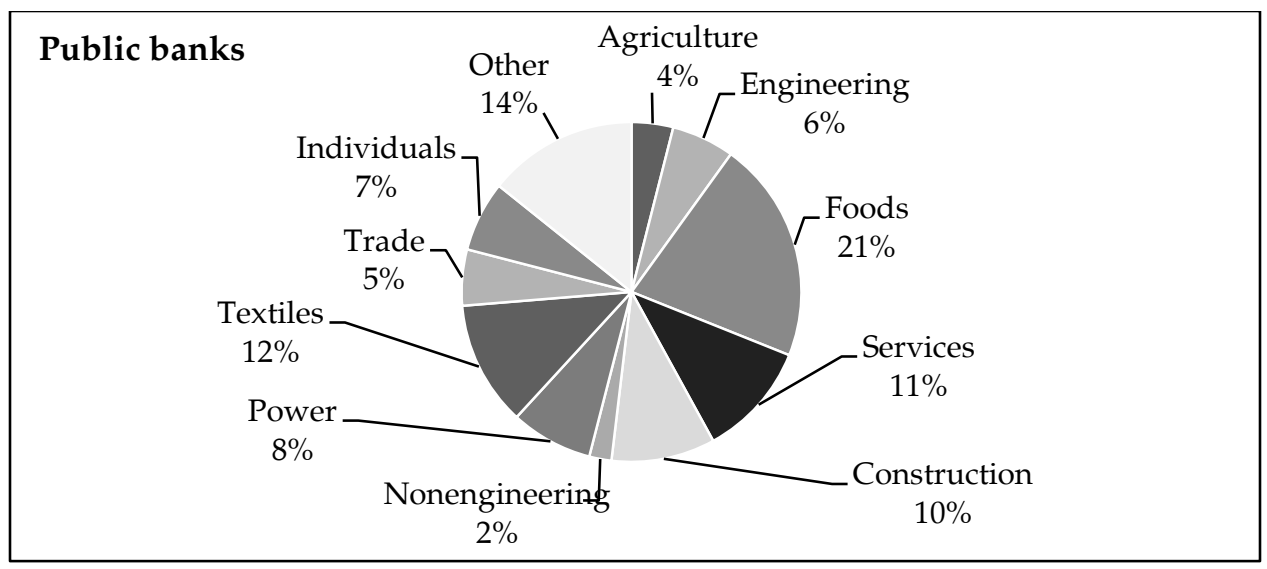



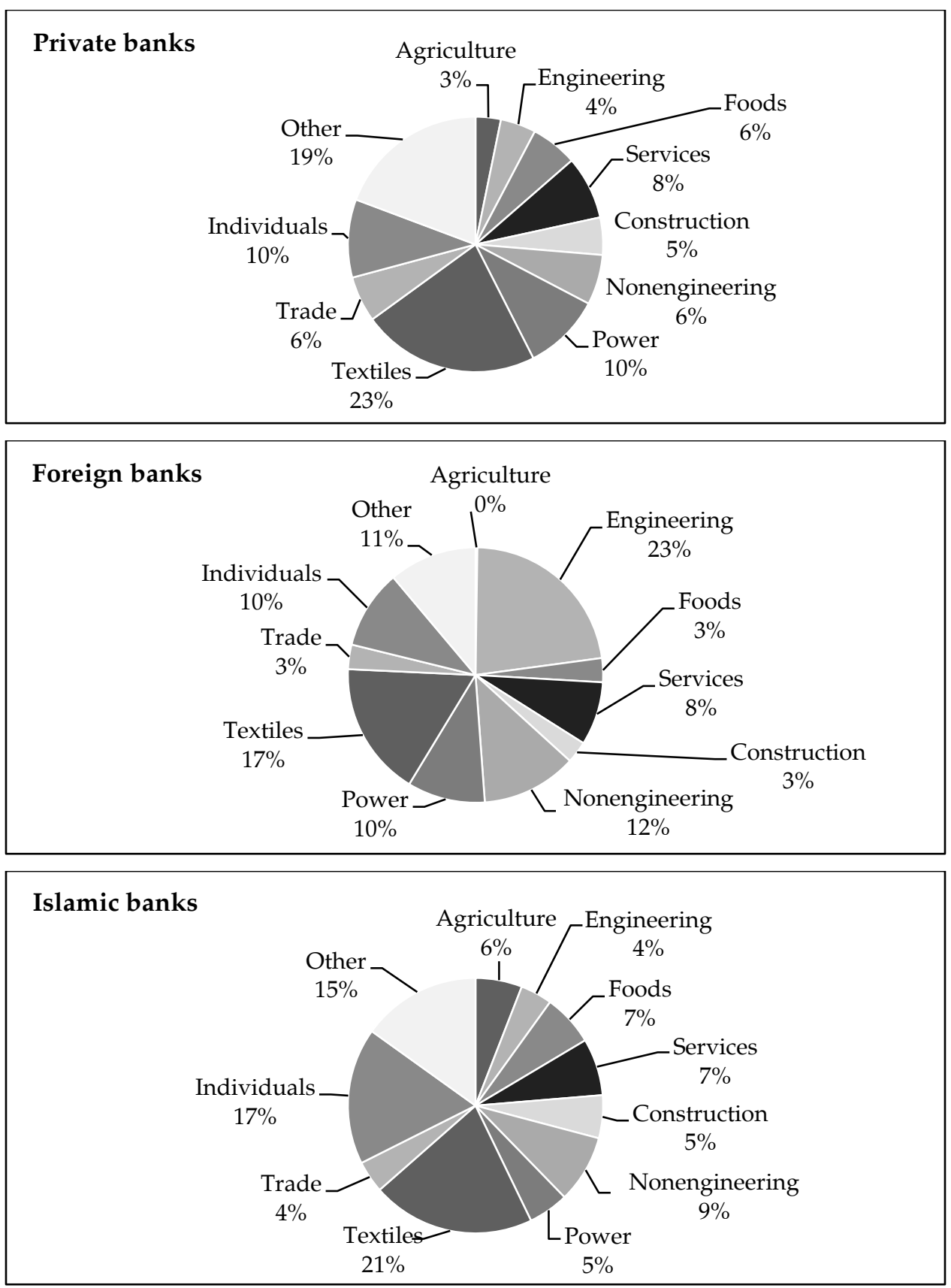

\section{Conclusion}

This study examines the performance of a sample of 34 commercial banks with reference to their credit portfolio management and NPLs. The analysis is conducted across four types of banks - public, private, foreign 
and Islamic banks - operating in Pakistan over the period 2008-12. We look at their lending behavior across 11 sectors: agriculture, engineering, foods, services, construction, nonengineering, power, textiles, trade, individuals and others. The study analyzes the differences in managerial decisionmaking based on the type of bank, which reflects its management structure, as well as the choice of priority lending sectors. We measure performance in terms of NPLs as a percentage of gross credit portfolios. To ensure robustness, we also use other proxies for NPLs, including the nominal value as a percentage of assets and as a percentage of gross loans.

The results suggest that the "other" sector is a priority lending sector, accounting for 19.47 percent of average gross credit portfolios. This is followed closely by the textiles sector at 19.15 percent of average gross credit portfolios. Overall, commercial banks' decision to lend to these two sectors does not appear to benefit the banks themselves: both sectors have a high infection rate, where the maximum level of NPLs is 19.74 and 16.40 percent of the average gross credit portfolio. Our analysis across different types of banks suggests that the foods, textiles and engineering sectors are favored by public, private, Islamic and foreign banks.

Finally, the study highlights some interesting results with respect to the credit policies of commercial banks. For example, despite the rise in NPLs in the banking sector, we observe an increasing trend in total assets and gross credit portfolios over the sample period. This implies that commercial banks have continued to support industry even at the cost of their own efficiency. 


\section{References}

Arif, A., \& Anees, A. N. (2012). Liquidity risk and performance of banking system. Journal of Financial Regulation and Compliance, 20(2), 182-195.

Balla, E., \& McKenna, A. (2009). Dynamic provisioning: A countercyclical tool for loan loss reserves. Federal Reserve Bank of Richmond Economic Quarterly, 95(4), 383-418.

Belgrave, A., Guy, K., \& Jackman, M. (2012). Industry-specific shocks and nonperforming loans in Barbados. Review of Finance and Banking, $4(2), 123-134$.

Bofondi, M., \& Ropele, T. (2011). Macroeconomic determinants of bad loans: Evidence from Italian banks (Occasional Paper No. 89). Rome: Bank of Italy.

Doyran, M. A. (2012). Evidence on US savings and loan profitability in times of crisis. International Journal of Business and Finance Research, 6(1), 35-51.

Hasan, I., \& Wall, L. D. (2004). Determinants of the loan loss allowance: Some cross-country comparisons. The Financial Review, 39(1), 129152.

Hou, Y., \& Dickinson, D. (2007, August). The nonperforming loans: Some bank-level evidences. Paper presented at the Asia-Link Conference on Safety and Efficiency of the Financial System, Manila, Philippines.

Ijaz, D., Haq, A., Naseem, M. A., \& Iqbal, J. (2012). Impact of privatization on nonperforming loans of conventional commercial banks in Pakistan. Academic Research International, 3(1), 322-332.

Isa, M. Y., Choong, Y. V., \& Fie, D. Y. (2013). Loan loss provisioning practices. Journal of Modern Accounting and Auditing, 9(6), 814-822.

Maggi, B., \& Guida, M. (2011). Modelling nonperforming loans probability in the commercial banking system: Efficiency and effectiveness related to credit risk in Italy. Empirical Economics, 41(2), 269-291. 
Premnath, D., Balachandran, S., \& James, G. (2013). A sector-wise analysis of nonperforming asset in state bank of Travancore. International Journal of Research in Commerce, IT and Management, 3(5), 82-87.

Sharma, M. (2005). Problem of NPAs and its impact on strategic banking variables. Finance India, 19(3), 953-967. 